extending the validity of the original agreement until 1947. Progress in collaboration has recently been effected by instituting a scheme which facilitates joint membership of two or three of the societies under payment of a reduced total fee ; and by giving members a wide choice of publications up to a sperified limiting value. The provisions of the deed aim primarily at 'roping in' as many as possible of the 14,000 (?) scientific chemists now practising their profession, with the view of promoting the progress and status of chemistry in its threefold aspect of science, profession and technical applications. Nothing appears to be said about the obligations of the profession to the community, but there is little doubt that these could be and would be far better met by a united profession than by what has been called "a disunited rabble"

\section{Rockefeller Foundation's Gifts to the National Central Library}

Ar a time when the Trustees of the National Central Library are faced with difficulties beyond the normal, as a result of the loss by enemy action of about half its books and the greater part of its London building, the emergency grant of $£ 2,200$ which has recently been made by the Rockefeller Foundation comes as a most welcome gift. Some of the books lost will be irreplaceable, but, fortunately, many of them can be bought as the demand for them arises. The timely aid of the Rockefeller Foundation will be appreciated by many thousands of persons who will benefit by the valuable additional service thus placed at their disposal. The grant is also another illustration of the practical sympathy of the United States with the difficulties which have to be dealt with by those responsible for the work of cultural institutions in the British Isles. By helping the National Central Library, the Rockefeller Foundation is indirectly helping all other libraries which make use of the national service. The Rockefeller Foundation is also continuing to provide money for the upkeep of the Bureau of American Bibliography at the National Central Library.

\section{Physical Society: Annual General Meeting}

Tнг sixty-seventh annual general meeting of the Physical Society was held on July 25 in the lecture theatre of the Science Museum, with Prof. Allan Ferguson in the chair. The reports of the Council and of the treasurer were adopted and the following officers for 1941-42 elected. President: Dr. C. G. Darwin; Hon. Treasurer: Dr. C. C. Paterson; Hon. Secretary (Business) : Dr. W. Jevons : Hon. Secretary (Papers) : Mr. J. H. Awbery ; Hon. Librarian : Dr. L. C. Martin; New Members of Council: Prof. E. N. da C. Andrade and Dr. H. Shaw. Prof. Ferguson will undertake the duty of acting-president until Dr. Darwin is able to take office. The Council has to record a very successful year's work in difficult circumstances. Despite exceptionally heavy losses by death, the membership of the Society is scarcely affected, standing at 1,070 members at the end of 1940 , as compared with 1,084 members twelve months earlier.
For the science meetings of the Society, the Council has adopted a new policy which has been justified by its complete success, the majority of the meetings having been devoted to discussions and to lecture-surveys. Discussions have been held on colour, the liquid state, the electrical and general physical properties of plastics, and the teaching of the fundamentals of electric and magnetic theory. Lecture-surveys have been given on contact-angles (Prof. Allan Ferguson), anemometry (Prof. P. A. Sheppard), gravity meters (Dr. J. McG. Bruckshaw), the magnetic hysteresis cycle and its interpretation (Prof. L. F. Bates), and some mechanical properties of glass (Prof. W. E. S. Turner). An outstanding event was the formation, within the ambit of the Society, of a Group for the discussion of scientific and technical problems relating to colour. The Group has already held three very profitable meetings, and its success encourages the initiation of similarly constituted groups for the discussion of problems of special interest to experts on the subjects to which the groups are devoted.

\section{A Clouded Yellow Butterfly Invasion}

ONE of the most interesting entomological features of the summer of 1941 is the invasion of clouded yellow butterflies (Colias croceus or Edusa) from the Continent which, since the first week of July, have been seen in Lancashire and Cheshire and various other parts of the north of England. This immigration has nothing to do with the War; it is one of the more spasmodic immigrations of insects which occur from time to time, the classic example being the 'great Edusa year' of 1877, when flights ranged from the Orkneys to Land's End and Ireland. Several were seen in 1933, 1926, 1913, 1872, 1864, 1862 and 1859 and odd specimens in the north in other years like 1930. The greenish-white variety helice Hubn. has also been seen, while the rarer pale clouded yellow (C. Hyale) was observed in 1860, 1872, 1891, 1900-1, and at least one specimen has been noted at Ness, west Cheshire, during the present immigration of clouded yellows. A few clouded yellows from south Europe reach the south of England almost every year, arriving during May or June; third brood larvæ are sometimes found in autumn on trefoil, lucerne or clover, and attempts at hibernation have been noted, but there is no record of surviving the winter here. Excepting in 1892, the common and pale clouded yellows are seldom abundant immigrants together.

\section{Mineral Composition of Crops}

IT is generally recognized that the mineral composition of crops has an important bearing on human and animal health, and increasing attention is being paid to the interrelationships between such fields of investigation as soils, fertilizers, plant composition and the nutritive value of food. Although it is true that several nutritional diseases can be directly traced to the deficiency or excess of particular minerals, as yet the data are usually quite insufficient for the laying down of direct recommendations for agricultural practice. A valuable review and com- 